\title{
DA VIDA HEROICA AO DIÁRIO ERÓTICO: SOBRE AS MORTES DE CURT NIMUENDAJU' ${ }^{1}$
}

Elena Welper

\section{Introdução}

But "sexuality" is not "kinship" nor "marriage" nor "alliance", it is more and less than of all these concepts (Markowitz \& Ashkenazi 1999:11).

Durante muitos anos a morte de Curt Nimuendajú (17/04/1883-10/12/1945) foi assunto de cartas e conversas sigilosas trocadas entre membros da comunidade antropológica brasileira. Isto se explica não apenas pelo longo processo de compra do seu espólio (que durou cerca de seis anos), mas sobretudo pelas circunstâncias trágico-misteriosas do evento e também pelo destino conturbado de seus restos mortais (ver Hartmann 1981, 1982; Pacheco de Oliveira 1986; Laraia 1988).

Curt Nimuendajú foi vitimado por uma súbita e fulminante crise hemorrágica pouco após a sua chegada à maloca ticuna do igarapé da Rita, no rio Solimões. O corpo foi enterrado no dia 11 de dezembro de 1945 no cemitério de Santa Rita do Weil, sendo o caso tratado como morte natural. Mas logo surgiram novas e diferentes versões para as causas da morte, e em todas elas Curt Nimuendajú aparecia como vítima de homicídio, mais especificamente de envenenamento.

Em linhas gerais, as versões de assassinato remetem a duas possibilidades: na primeira, Curt Nimuendajú teria sido envenenado pelos brancos, na segunda, pelos índios. Sobre os motivos para o crime as versões são mais variadas, e revelam as múltiplas perspectivas sobre o fazer etnográfico deste pesquisador. Este artigo pretende recuperar os principais fatos e personagens dessa história utilizando-se para tanto da bibliografia existente, mas principalmente de documentos e depoimentos inéditos colhidos no âmbito da minha pesquisa de pós-doutorado, bem como cadernetas de viagem e cartas depositadas no Arquivo Curt Nimuendajú. ${ }^{2}$ 
Neste percurso, além de complementar o último trabalho de Pacheco de Oliveira sobre a pesquisa de Curt Nimuendajú entre os Ticuna, no qual este autor optou por "[...] proceder a uma etnografia da situação de pesquisa, procurando apreender os padrões de interação, as expectativas e crenças que decorreram desse relacionamento" (Pacheco de Oliveira 2013:232), este artigo problematiza as dimensões pessoais do fazer etnográfico e esbarra num debate mais amplo que emergiu nos anos 1990 sobre o tema da identidade e da subjetividade erótica no trabalho de campo (Kulick \& Willson 1996; Markowitz \& Ashkenazi 1999).

Partindo da premissa de que a postura convencional do etnógrafo como um ser assexuado seria impossível de ser sustentada - ao menos da perspectiva nativa - os textos reunidos nestas coletâneas tiveram o objetivo de romper o "silêncio" sobre o tema, trazendo-o para a discussão sobre trabalho de campo e mostrando-o como parte de um processo de comunicação intersubjetiva que pode ou não funcionar. Na visão desses autores, sexo e sexualidade são componentes essenciais para as posições e as relações que constituem o encontro etnográfico e devem ser assim amplamente reconhecidos (Kulick 1996; Markowitz \& Ashkenazi 1999).

\section{Nimuendajú e os Ticuna}

Quando Nimuendajú decidiu iniciar sua pesquisa de campo entre os Ticuna, no final de 1940, já era um etnógrafo de fama internacional, consagrado pelos resultados de suas pesquisas entre os povos Jê, as quais desejava ainda concluir - por compromisso científico - após uma investigação nas regiões Sul e Sudeste. Robert Lowie, da Universidade da Califórnia, e Heloisa Alberto Torres, diretora do Museu Nacional, muito se empenharam para financiar tais viagens, mas as restrições econômicas ocasionadas pela Segunda Guerra e a falta de certeza sobre os resultados dessa pesquisa entre os índios daquelas regiões fizeram com que Nimuendajú decidisse mudar de área, optando por um lugar mais distante do "progresso". ${ }^{3}$

Na interlocução com Robert Lowie, Curt Nimuendajú considerou a possibilidade de ir para os Mundurucu, mas acabou por manifestar sua preferência pelos Ticuna. Entre as vantagens deste campo, Curt Nimuendajú elencava: as características sociológicas do grupo (organização em clãs, rituais de puberdade etc.); a maior densidade demográfica e o fato de a região ter inúmeras outras possibilidades de estudo; o acesso às aldeias por vias fluviais; a ausência de missionários e pesquisadores; além do contato prévio que já havia estabelecido com o grupo em 1929. 
Ali, segundo o próprio Nimuendajú, ele teria que tratar apenas com os "patrões":

Os Tukuna não estão sendo subordinados a missionários, mas sim a patrões brasileiros que apenas se importam de se assegurar da produção de borracha e farinha de mandioca dos índios, que, no entanto, além disso, pouco se preocupam com o que eles acreditam ou façam. Por estas razões puramente comerciais, eles mantêm todas as outras comunicações longe dos "seus" índios, o que para estes, afinal só é uma vantagem. - Nos Munduruku, por outro lado, existe além da missão a livre concorrência dos comerciantes. ${ }^{4}$

Lowie respondeu positivamente aos planos de Nimuendajú, mas expressou sua preocupação com os riscos que esta viagem poderia trazer à sua saúde.

O que o senhor me conta dos Tukuna interessa-me vivamente. Insinuações a respeito o senhor já fez antes. Por serem as condições nesta tribo tão favoráveis, só posso aprovar o seu plano. Mas deve-se considerar também o seu estado de saúde. Eu teria sérios remorsos se uma viagem de pesquisa a ser empreendida pelo senhor por minha iniciativa causasse consequências maléficas para o senhor. Se não me engano, somos o senhor e eu exatamente da mesma idade (farei em junho 58 anos), e embora não tenha motivos para me queixar, não consigo me julgar capaz como ainda há oito anos. ${ }^{5}$

\section{A primeira visita aos Ticuna}

O primeiro contato de Nimuendajú com os índios Ticuna ocorreu em novembro de 1929 quando ele, em uma viagem de 15 dias pelo alto Solimões, visitou os índios dos igarapés Belém (Caldeirão) e Preto (também chamado de São Jerônimo), e do lago Cajary. ${ }^{6}$ Os dados coletados nesta breve viagem foram apresentados em um relatório de 11 páginas enviado ao Serviço de Proteção aos Índios ${ }^{7}$ e em um artigo publicado no ano seguinte no periódico Ethnologische Anzeiger. ${ }^{8}$

Naquilo em que estes textos não se repetem, eles se complementam, visto que o primeiro tinha uma finalidade mais política e o segundo, científica. Não me ocuparei aqui em apontar as diferenças entre os respectivos textos, pois isto já foi satisfatoriamente feito (ver Moreira Neto \& Emmerich 1977; Schroeder 2013), mas vale destacar as impressões que levaram Curt Nimuendajú de volta aos Ticuna, um povo que, segundo ele, possuía uma "índole mansa e pacífica" (Nimuendajú 1977 [1929]:23). 
Embora Curt Nimuendajú tenha registrado que o tradicional sistema de barracão afastava os jovens do convívio com a "tribo" e permitia uma danosa intervenção do patrão na vida particular dos índios, em especial nos seus costumes religiosos, não considerava que aqueles representassem a pior das influências:

Os males que o trabalho no barracão causa aos índios têm a sua origem muito menos na pessoa do seu atual patrão, e mais no caráter do seu estabelecimento, pois são as consequências funestas do industrialismo em geral e do álcool. Este último é sem dúvida pior e os seus efeitos dão imediatamente à vista: comparados com os índios do igarapé Preto, onde a cachaça só aparece excepcionalmente e em diminutas quantidades, os do igarapé Belém causam a impressão de fracos, menos sadios e degenerados. Notei com enorme satisfação o esforço do atual patrão em reduzir ao mínimo possível as rações de cachaça, contrariando mesmo com isto os índios que se queixaram a mim de que no tempo de seu antigo patrão, o finado Sr. Romualdo Mafra, eles recebiam a cachaça à vontade (Nimuendajú 1977 [1929]:54).

Além disto, Curt Nimuendajú observou que, embora eles fossem "mal recompensados", não lhes faltavam "as mercadorias mais necessárias", como roupas, mosquiteiros e ferramentas agrícolas, e que apenas poucos índios estariam endividados (Nimuendajú 1977 [1929]:54). Também destacou o "bom estado sanitário" dos índios, em especial os do igarapé Preto - que eram "exclusivamente" seringueiros e trabalhavam para Manuel Mafra - notando "com grande satisfação a cordialidade existente entre a família do patrão e as dos índios" (Nimuendajú 1977 [1929]:57). Mesmo no seringal do igarapé Belém, onde faltaria "este quadro atraente" por ser o patrão dali um "homem solteiro", não haveria dificuldades para recrutar novos empregados, pois "o tratamento durante o trabalho não é mau. O arrendatário não permite que os seus encarregados tratem os índios com aspereza e impõe respeito às famílias deles" (Nimuendajú 1977 [1929]:53) . Neste local, porém, onde se produzia borracha, açúcar e cachaça, os índios teriam uma "aparência degenerada, fraca" por efeito do alcoolismo que ali existia (Nimuendajú 1977 [1929]:22).

\section{A segunda viagem aos Ticuna}

Com o último subsídio financeiro que recebeu de Robert Lowie e as lembranças daquela sua primeira viagem, Curt Nimuendajú voltou aos Ticuna 
preparado dessa vez para uma longa viagem de reconhecimento do território ticuna, a qual ficou registrada no seu diário. ${ }^{9}$

Curt Nimuendajú partiu de Belém no dia 22 de fevereiro de 1941 e chegou a Manaus no dia 03 de março. Nesta cidade encontrou-se com o amigo Gerhard Lindenberg (um diplomata alemão) e alguns "jovens do Instituto Histórico". Também passou pela Inspetoria do Serviço de Proteção aos Índios e, a fim de contar com a boa vontade dos patrões do rio Solimões, procurou a matriarca da família Mafra - "dona Yayá Mafra" - mas esta pareceu não se empenhar em conhecê-lo (Nimuendajú 2000:287).

A viagem de Manaus até Tabatinga durou cerca de duas semanas e foi acompanhada de dores de ouvido, dores de cabeça e diarreia. Em Tabatinga, de onde pretendia logo iniciar a descida do rio Solimões, encontrou dificuldades para comprar uma canoa que servisse para a viagem, gastando mais tempo e dinheiro do que previa.

Em 08 de abril Curt iniciou a descida do rio Solimões, fazendo a parada seguinte no Barracão Perpétuo Socorro (na boca do igarapé Belém), que era propriedade de Quirino Mafra, um dos maiores proprietários de terra daquela região. Depois de uns dois dias, Curt Nimuendajú se dirigiu para o igarapé São Jerônimo à procura de um "velho conhecido", o ticuna de "meio-sangue" Calixto Dauerucü, um "caboclo interessante cujo pai era um velho alemão da família Weil, morador na beira do Solimões". Sua mãe era uma conhecida anciã ticuna, filha de um importante xamã daquele tempo. De acordo com Nimuendajú, Calixto era o "último" ticuna brasileiro que fabricava o curare (Nimuendajú 2000:289-291). Apesar dessa interessante figura, este grupo local causou grande decepção em Nimuendajú, evidenciando assim, na sua visão salvacionista, a necessidade urgente de registrar a cultura ticuna:

[...] Estão horrivelmente civilizados. Assim parece, pelo menos à primeira vista, e de fato, a sua cultura material original esta reduzida a mais ou menos um terço, e a espiritual, grandemente influenciada. Creio que muitos etnólogos, vendo esses índios tão descentemente vestidos, caçando com espingardas de cartuchos e lumiando nos seus igarapés virgens com lâmpadas elétricas de algibeira, pensariam que eu esteja perdendo o meu tempo. Para mim esse estado só me demonstra a necessidade premente de salvar o que ainda pode ser salvo (Nimuendajú 2000: 289-290).

Enquanto esteve no igarapé São Jerônimo, Curt Nimuendajú fez uma peregrinação pelas malocas e os lugares sagrados, incluindo o mítico igarapé Eware, de onde os Ticuna seriam originários. Conforme Pacheco de Oliveira, a visita de Nimuendajú "ao local sagrado do Eware reforçou os vínculos afetivos 
com os Ticuna" e contribuiu para a identificação que já estava sendo feita entre o etnólogo e o personagem mítico Tecu-quira, filho do herói cultural Ipi (Pacheco de Oliveira 2013:239). Sobre isto Curt relatou ao amigo Carlos Estevão:

Aquilo que me parecia a maior dificuldade, fazer esses índios falar, está agora já de certo modo removido: pela minha romaria à terra dos mitos, pela minha atitude afirmativa para com a cultura antiga e pela minha liberdade no trato estou certo de que já conquistei a simpatia e a confiança da maioria dos Tukúna. Onde quer que eu apareça junta-se a mim imediatamente um bando de índios (o que mais das vezes para mim não é vantagem nenhuma) que interrogam o dono da casa e os índios meus remadores sobre o que eu fiz e disse; por força querem que eu saiba onde hoje em dia habita o herói cultural Dyói e consultam-me em matérias tão difíceis como sejam questões de incesto. Noráne, desde que me conheceu, afirma a todos que querem saber como era a pessoa que lhe apareceu, que ela se parecia extremamente comigo, e numa nova visão ele me viu em companhia das pessoas mitológicas. Tudo isto se dá apesar de eu ter evitado tudo que possa dar margem para mistificações, afirmando aos índios que NADA sei e que vim para aprender! (Nimuendajú 2000:298).

Apesar das boas relações estabelecidas com os índios deste igarapé, quando estes foram convocados a trabalhar no seringal, Nimuendajú viu-se forçado a deixar a hospitaleira casa de Calixto (Pacheco Oliveira 2013:250). Foi então que se transferiu para o igarapé da Rita onde encontrou índios que não eram seringueiros, e estavam preparando uma festa da puberdade (Nimuendajú 2000:297). Ali, Curt Nimuendajú ficou junto à família de Nino Ataíde Evenique, que se tornou um de seus principais informantes (Nimuendajú 1952:39).

Ciente das relações de poder exercidas pelos patrões da região e da necessidade de seu consentimento para a continuidade de suas pesquisas, Nimuendajú procurava manter boas relações com os "civilizados", em especial com Quirino Mafra (patrão do igarapé São Jerônimo), e Nilo Müller (comerciante da vila de Santa Rita do Weil), que foram escolhidos para receber a correspondência que enviaria para seus informantes Calixto e Nino Ataíde, respectivamente.

Logo após seu retorno a Belém, ainda no mês de outubro de 1941, Nimuendajú escreveu para Quirino Mafra enviando junto algumas fotografias que deveriam ser entregues a Nino Calixto. ${ }^{10}$ No começo do ano seguinte, Nimuendajú escreveu conjuntamente para Nilo Müller e Nino Ataíde, anunciando que em fins de abril ou começo de maio daquele ano (1942) chegaria a Santa Rita, enviando lembranças a outros moradores não indígenas da vila: Laureano, Carlos Müller e Henrique Geissler. ${ }^{11}$ A carta-resposta de Nino 
Ataíde traz alguns pedidos e informa sobre o adoecimento de alguns ticunas que lhes eram conhecidos. ${ }^{12}$ Da parte de Calixto, porém, Nimuendajú nada recebeu, levando-o a escrever novamente ao "caro amigo" Quirino Mafra, ${ }^{13}$ pedindo que este transmitisse a Calixto seus planos para a viagem de volta aos Ticuna. Remetia junto um envelope selado para ser usado na resposta, mas esta nunca foi enviada.

\section{A terceira viagem aos Ticuna}

A terceira viagem de Curt Nimuendajú para os Ticuna foi financiada pelo Museu Nacional e previa um período semelhante de duração (seis meses). O roteiro, porém, não incluiu a área de Tabatinga e supunha o seu estabelecimento junto à família de Nino Ataíde, no igarapé da Rita.

Durante a sua passagem por Manaus, como de costume, encontrou-se com os amigos G. Lindenberg e Manuel Nunes Pereira, fez compras nas Pernambucanas e reuniu-se na Inspetoria do Serviço de Proteção aos Índios, onde conseguiu dissuadir o inspetor geral do Amazonas, Alberto Jacobina Pizarro, da ideia de instalar um posto e uma escola no igarapé Belém, que havia sido formulada pelo patrão deste seringal, Antônio Roberto Ayres de Almeida, primo de Quirino Mafra.

No dia 21 de abril de 1942, Curt Nimuendajú pegou o vapor para Manaus acompanhado de Carlos Correa, funcionário do SPI que viajava com a missão de fundar o Posto Indígena no alto Solimões. Em 01 de maio, Curt Nimuendajú desembarcou em São Paulo de Olivença, de onde despachou algumas cartas pelo correio, visitou o prefeito Alcides Câmara, e seguiu viagem até a vila de Santa Rita do Weil:

No dia 2 de maio cedo desembarquei em Santa Rita, e à uma hora da tarde cheguei na casa do meu amigo, o Tukúna Nino que já não me esperava mais, pois era fato sabido entre civilizados e índios da zona que eu tinha sido morto. Segundo ele, preso por ter viajado sem licença e morto por ser espião alemão. [...] Muitos Tukúna, aliás, não acreditaram na história da minha prisão e morte, e achei-os esperando pacientemente, alguns com as suas filhas moças já há meses em reclusão, para que eu viesse assistir às suas festas (CN-CE, 09/05/42 apud Nimuendajú 2000:308) .

De acordo com seu diário de viagem ${ }^{14}$ dois dias depois de chegar à maloca de Nino (04/05), Nimuendajú foi para Santa Rita com a intenção de visitar os "civilizados" daquela vila, isto é, além dos comerciantes alemães 
da família Müller (Carlos, Laureano e Nilo), o carioca Barcellos e Júlio Pinto. A viagem foi perdida, pois lá não encontrou ninguém, um primeiro sinal do clima hostil que o rondaria por toda essa temporada de campo:

A 1 de junho estava de volta no Igarapezinho onde Calixto também tinha chegado na mesma hora. Dele tive então ampla confirmação daquilo que eu mesmo já reconheci depois da carta que eu lhe escrevi: que, quanto aos boatos a respeito da minha pessoa, não se tratava apenas de mentirazinhas ingênuas do "povo", mas de uma campanha sistemática de difamações e calúnias encabeçadas por Antônio Roberto e executadas principalmente pelos irmãos Quirino, Boaventura e Roberto Mafra. [...] Completamente falha foi essa campanha entre os Tukuna. Se bem que acreditassem que eu estivesse impedido de voltar ou mesmo morto, os sentimentos para comigo nada mudaram e em toda parte a sua alegria de ver-me novamente foi impressionante. Evitei desde então a casa dos Mafras: Quirino tinha me tratado, como nunca deixei de reconhecer abertamente, com muita hospitalidade. Tinha eu a ilusão que essa hospitalidade fosse a manifestação de algum sentimento nobre, e que lhe devia gratidão por ela, mas foi engano meu: é apenas um gesto oco e convencional, como, por exemplo, aquele de se tirar o chapéu quando se passa por uma igreja, e perfeitamente compatível com ódio e hostilidade contra o mesmo hóspede (Nimuendajú 2000:310-311).

Após encerrar seu trabalho de campo, quando estava a bordo do navio que o levaria a Manaus, Curt Nimuendajú recebeu ordem de prisão, mas chegando a esta cidade foi "solto imediatamente e sem mais formalidades" graças aos esforços de Carlos Estevão. ${ }^{15}$

Convicto de que sua prisão fora orquestrada pelos patrões do Solimões, Curt Nimuendajú entendeu o episódio como uma ameaça e não mais escreveu a Quirino Mafra. ${ }^{16}$ Manteve, porém, a correspondência com o alemão Nilo Müller e Nino Ataíde, enviando retratos, fazendo orientações, elogiando as peças coletadas e prometendo gratificações. Por fim avisa que não viajaria em breve, mas que ainda voltaria para escrever mais "histórias em língua Ticuna". ${ }^{17}$

\section{Em tempos de guerra, trabalho de escrivaninha}

Embora Curt Nimuendajú reconhecesse a necessidade de retornar ao campo, o cenário político não permitiu que o fizesse no tempo planejado, levando-o a se dedicar ao trabalho de escrivaninha que, naquele momento, consistia na elaboração da monografia Ticuna ${ }^{18}$ e nos artigos para o Handbook of South American Indians, até ser convidado por Rondon para assumir a chefia das 
investigações etnológicas do Conselho Nacional de Proteção aos Índios. Com este propósito, Nimuendajú viajou para o Rio de Janeiro, e nesta viagem descobriu que sofria de glaucoma. Em carta para Alfred Metraux, um de seus maiores admiradores, Curt contou que em razão de seu estado clínico geral era recomendado que abandonasse a sua vida de sertão e a convivência com os índios, pois de outra forma não seria possível cumprir a dieta que lhe era necessária. ${ }^{19}$ As cartas seguintes para este interlocutor demonstram a tristeza que isto lhe causava:

Portanto, depois de quase 40 anos, a minha atividade em convivência com os índios chegou ao seu fim quando eu menos esperava. O Sr. compreenderá como isto me entristeceu, sabendo como sabe que essa vida era toda a minha satisfação. Além do que eu pensava fazer ainda muitas coisas que agora talvez nunca mais serão feitas. ${ }^{20}$

Embora as cartas para Metraux ameaçassem o fim de suas atividades de campo, a correspondência com os "amigos" de Santa Rita do Weil indicava que mantinha os planos de voltar no ano seguinte. Em outubro de 1943, Curt Nimuendajú escreveu para Nino Ataíde informando que voltaria no ano seguinte para "... escrevermos mais histórias em língua tukúna ainda"21 e no mês seguinte escreveu a Nilo Müller notificando o envio de retratos (junto com os negativos) para várias pessoas, entre elas Henrique Geissler ${ }^{22}$ e Barcellos. ${ }^{23}$ Por fim, confirmava o seu retorno no ano de $1944 .{ }^{24}$

Mas tão logo chegou 1944, Curt Nimuendajú se viu obrigado a abandonar a perspectiva de voltar aos Ticuna naquele ano. Em carta para Nino Ataíde informou que só voltaria depois de março de 1945, mas que enviaria as miçangas para sua filha Celina. ${ }^{25}$

Para Nino Ataíde, que esperava Nimuendajú (e suas miçangas) para a festa de puberdade de sua filha, o atraso de Nimuendajú era especialmente desolador, levando-o a considerar uma oferta feita pelo frei Fidelis ${ }^{26}$ de levar suas filhas para estudar no convento e, com isso, desistir das cerimônias tradicionais. Curt Nimuendajú, porém, orientou Nino a recusar a oferta de frei Fidelis, confirmando suas intenções de retorno.

Quanto à proposta de frei Fidelis deixa que eu lhe diga a minha opinião: se você achar uma boa ocasião para o Miguel aprender a ler e escrever, aproveita. Mas as suas filhas você não deve dar para ninguém, nem para o colégio, nem como empregadas. Você é um homem sabido e trabalhador, e pode muito bem criá-las em casa. Debaixo da guarda da dona Anizia elas estão melhor que no colégio de freiras. Além do que, daí a alguns meses, Neves ficará moça e tem 
de ir para o curral, e vocês devem fazer a cantiga de vareki para ela. Foi esta a lei que dyaí deixou para a nação Tukúna, e vocês devem cumpri-la.

Se frei Fidelis lhe disse que eu já não voltava mais ao Solimões, ele está enganado. Quando eu estive no Rio e fiz meu contrato com o Museu Nacional de lá, ficou assentado que eu voltaria aos Tukúna. [...] creio que até o começo do ano vindouro eu voltarei [...], pois nós dois temos de escrever ainda muitas outras histórias destas, e só por causa disso eu não posso deixar de voltar. ${ }^{27}$

Nino Ataíde não respondeu a esta carta, e Nimuendajú sabia por quê. No final daquele ano ele escreveria a Nilo Müller assumindo o estranhamento por não ter obtido mais resposta de Nino Ataíde e explicando que "tem de se entender com Nino, quer certa gente do Solimões goste disso ou não", pois voltaria ao Solimões em janeiro do ano seguinte (1945) junto com uma equipe do Instituto Agronômico. ${ }^{28}$

Esta viagem não se realizou e apenas após a iminência do fim da guerra ele voltaria a se comunicar com Nilo, dando notícia dos novos trabalhos junto a Rondon e da decisão de voltar aos Ticuna. ${ }^{29}$ No final de setembro escreveu novamente para Nino informando que aguardava o vapor para Manaus com as compras das encomendas já feitas, e termina a carta mandando notícias a Nilo Müller, Henrique, Barcellos e "nossos amigos todos". ${ }^{30}$

\section{A última viagem}

Em novembro de 1945 Curt Nimuendajú partiu de Belém para Manaus, onde ficou por 15 dias ocupado com compras, assuntos indigenistas e amigos. Almoçou várias vezes com Arthur Neiva, da Fundação Brasil Central, e participou das reuniões de gestão que o inspetor Jacobina estava realizando para a aquisição de terras da Reserva Ticuna Umariaçu, em Tabatinga. Por esta razão, antes de partir de Manaus, Nimuendajú forneceu um mapa que indicava os limites daquela reserva e foi nomeado por Jacobina para exercer as funções de "Delegado de Índios" do alto Solimões (Pacheco de Oliveira 1986:261). De acordo com Nunes Pereira, que já havia estado em 1944 junto aos Ticuna do igarapé da Rita e planejava voltar ao Solimões nesta temporada em que Curt estaria em campo, sua "presença em Manaus foi muita festejada" por todos que o conheciam ou passaram a conhecê-lo. Ainda de acordo com Nunes Pereira, Nimuendajú teria se manifestado contra Nino Ataíde, por este estar "trabalhando para o patrão Nilo Weil". ${ }^{31}$

Em 21 de novembro Curt Nimuendajú embarcou no vapor INCA e, após uma viagem de aproximadamente duas semanas, em 06 de dezem- 
bro, desembarcou em São Paulo de Olivença ${ }^{32}$ de onde no dia seguinte (7 de dezembro) escreveu breves cartas para pelo menos seis colegas. A carta mais longa foi dirigida a Harald Schultz e esclarecia pontos sobre a nomenclatura e língua ticuna, sobre vocabulários colhidos por Rondon e explicava também sobre os acontecimentos que fizeram com que desistisse de trabalhar para a Fundação Brasil Central. ${ }^{33}$ Para o desconhecido "Herr Host", ele comunica a chegada no dia anterior (06/12) e pede uma cópia da publicação de frei Fidelis no Boletim Bibliográfico do Museu Paulista (1944); e para Protássio Frickel, a quem agradece o envio de seu último trabalho, informa que subiria no dia seguinte (08/12) para o Igarapé da Rita. $^{34}$

As próximas notícias sobre Curt Nimuendajú seriam sobre sua morte.

\section{A “última hora” de Curt Nimuendajú}

De acordo com Barcellos, que residia na vila de Santa Rita e forneceu um primeiro relato sobre a morte de Nimuendajú, este teria ficado dois ou três dias em São Paulo de Olivença, até subir para o igarapé da Rita, acompanhado dos índios que vieram buscá-lo. Ao seu destino final, a maloca de Nino Ataíde no igarapé da Rita, teria chegado às 10 horas da manhã do dia 10 de dezembro, algumas horas depois sendo acometido por uma súbita hemorragia:

Logo ali ao chegar passou a distribuir presentes aos índios em regular que lhe fizeram uma recepção, tendo isso terminado pelas 16 horas mais ou menos daquele dia, tendo o sr. Curt mandado que os índios cada um voltasse às suas barracas, indo após tomar banho e jantando pelas 17:30 horas, uns peixes pacus, ao que depois de um certo tempo dissera aos índios [e] Nino, onde se achava hospedado; sr Nino estou muito cansado e quero me deitar, porque peço que arme já o meu mosquiteiro, ao que obedeceu o sr. Nino, tendo o sr. Curt ido logo a deitar. Tendo também se deitado o sr. Nino e pegado no sono, acordou com os chamados de sua mulher, dizendo: Nino acorda, Curt esta tossindo muito vai ver. Levantando ligeiramente Nino foi ao mosquiteiro do sr. Curt que já o encontrou debruçado, havendo deitado uma poça enorme de sangue, enquanto Nino diz - que é isso sr. Curt - O sr. Curt foi se virando dizendo - ai sr. Nino e morrendo. - foram as suas palavras - velado somente como digo, debaixo das luzes de lamparinas e fachos passou a noite o cadáver que não pôde ser trazido para a vila devido a uma chuva torrencial que caiu a noite toda e moderando pela manhã de 11, sendo enterrado [n]a tarde desse dia na 
Vila de Santa Rita, onde lhe prestaram assistência, digo ao seu corpo - dois alemães seus patrícios. ${ }^{35}$

Em fevereiro de 1946, Barcellos forneceria uma descrição mais detalhada:

Curt Nimuendajú passou pelo meu porto na vila de Santa Rita do Weil, às 6 1/2 do dia 10 de dezembro, tomou café comigo e prosseguiu viagem às 7 1/2 horas, sendo seus remadores 4 índios tucunas que o vieram remando desde São Paulo de Olivença, onde o foram buscar a chamado de Curt. ${ }^{36}$

De acordo com Barcellos, Nimuendajú teria chegado na maloca de Nino por volta das 11 horas, onde Curt teria almoçado uns "pirarucu com banana" e depois passado "o resto do dia conversando com diversos índios que aí foram recebê-lo, distribuindo muitas encomendas que para os mesmos trouxera".

Às 16 horas [Curt] fez dispersar todos os índios que não eram da casa de Nino, tomou banho, barbeou-se e jantou peixe "pacu" e tomou um copo de garapa, e em seguida deitou-se, isto pelas 18 horas e meia. Decorridos uns 20 minutos, Nino escutou u[ns] ruídos como quem estivesse regurgitando e correu ao mosquiteiro de Curt a quem encontrou fazendo esforço para erguer-se. Nino ergueu-o, quando Curt proferiu as palavras: "ai Nino", expirando em seguida. Nino verificou pelo relógio pulseira do extinto que o óbito ocorreu precisamente às 19 horas.

Após o falecimento de Curt, Nino comissionou 4 índios, para chamar-me a fim de verificar o acontecido, tendo chegado os ditos portadores à minha casa na vila de Santa Rita do Weil pelas 22 horas ainda no dia 10 de dezembro. Recebendo tal recado, imediatamente segui viagem, tendo convidado mais 4 civilizados que me acompanharam até a residência de Nino, onde chegamos às 2 horas do 11 . Tudo isto debaixo de uma chuva torrencial.

Aí chegados, encontramos o cadáver já vestido e uma multidão de índios dos dois sexos ao redor.

Passamos aí até as 5 horas, quando amainou um pouco a chuva, levamos o cadáver para a vila de Santa Rita do Weil, onde foi sepultado no cemitério público aí existente as 14 1/2 horas do dia 11 de dezembro, tendo sido previamente examinado por diversas pessoas, parecendo que a causa da morte tenha sido uma congestão pulmonar. ${ }^{37}$

No mesmo dia de seu enterro, em 11 de dezembro, o chefe de Polícia de São Paulo de Olivença enviou um telegrama ao chefe de Polícia de Manaus (Sebastião Moraes) notificando a morte de Nimuendajú. Esta informação 
chegou diretamente a Nunes Pereira, que a transmitiu ao diretor do Museu paraense (Carlos Estevão) e ao inspetor Jacobina. Nunes Pereira também orientou o delegado de Manaus a cuidar do espólio deixado em campo e depois chamou a atenção de José Maria da Gama Malcher, chefe da $2^{\mathrm{a}}$ Inspetoria Regional do SPI em Belém, para o valor científico do espólio que se encontrava na residência do pesquisador. ${ }^{38}$

Nunes Pereira foi o primeiro e um dos mais sensíveis biógrafos de Curt Nimuendajú. ${ }^{39}$ Em sua apresentação sobre o falecido pesquisador (Curt Nimuendajú. Síntese de uma vida e obra, 1946), ele não apenas recupera a trajetória de Nimuendajú, mas também destaca o espírito jovial, romântico e republicano do cientista autodidata. Isto, porém, parece ser menos mérito da intimidade que efetivamente existiu entre os dois do que da veia "jornalística" e germanófila de Nunes Pereira. ${ }^{40}$

Nunes Pereira estudou na Alemanha, onde deixou um filho e mantinha uma grande admiração pelos viajantes e etnógrafos alemães que desbravaram a Amazônia (Correa 1985). Alguns anos antes, Nunes Pereira fora protagonista do episódio que envolveu o translado dos restos mortais de Koch Grünberg, ${ }^{41}$ e naquele momento em que já se punha a redigir um "livro" sobre Nimuendajú, também planejava uma viagem para a coleta de depoimentos em São Paulo de Olivença, conforme comunicou a Gama Malcher:

Espero poder viajar em princípio de janeiro, com destino ao Peru: tenho o propósito, porém, de saltar em São Paulo de Olivença e ir a Santa Rita recolher depoimentos dos próprios caboclos Tukuna e de pessoas relacionadas com o Curt em Santa Rita. Curt tinha ali inimigos rancorosos das suas atitudes em defesa dos caboclos. Peço a V., entretanto, silenciar este detalhe, para que não venha a prejudicar qualquer pesquisa ou diligência. ${ }^{42}$

Nesta mesma carta Nunes Pereira informa que havia escrito para um "amigo alemão", que morava pouco abaixo do Igarapé da Rita, pedindo maiores detalhes sobre o ocorrido e descreve como foram os últimos dias de Nimuendajú em Manaus:

[...] o Curt desde que aqui chegou teve perturbações de certa importância, do fígado e do intestino, tendo consultado por isso um médico, o Dr. Conte Telles, atribuindo à mudança da alimentação tais achaques, que sempre se verificavam quando chegavam a Manaus. [...]. Deu-me a ler o trabalho referente aos Tukuna [...] dir-se-ia que me estava dando elementos para apreciar a obra, caso não voltasse dessa quarta viagem ao Solimões $[\ldots] .^{43}$ 


\section{Uma investigação secreta}

Em janeiro de 1946, o inspetor Jacobina solicitou ao chefe do Posto Indígena de Tabatinga, Manoel Pereira, vulgo Manoelão, que apurasse sobre as circunstâncias da morte de Curt Nimuendajú, orientando-o a indagar das testemunhas de sua viagem de barco até São Paulo de Olivença sobre seu aparente estado de saúde (Pacheco de Oliveira 1986).

O primeiro ofício-resposta de Manoelão (16 de janeiro de 1946) trouxe algumas informações que lhes foram transmitidas por "um índio que viajou até este Posto, para comunicar a referida morte". O índio era Nino Ataíde e seu depoimento foi registrado no relatório que alguns dias depois foi enviado ao inspetor Jacobina (Pacheco de Oliveira 1986:264).

O relatório registra a hipótese de assassinato, atribuindo a causa mortis a um envenenamento provocado pelos regionais, pois "quase todos os civilizados que moravam naquele lugar não gostavam do professor porque ele era um grande defensor dos direitos dos índios", e fornece uma descrição sucinta dos acontecimentos desde a chegada de Nimuendajú ao igarapé da Rita até o seu enterro em Santa Rita do Weil:

Depois de u[ns] dois dias que estava naquele igarapé, o professor saiu da casa do índio e foi fazer um passeio e, neste percurso, tomou uma xícara de café em casa de um civilizado que o comunicante não soube explicar direito. Quando chegou em casa, passados momentos, ele foi atacado por uma súbita convulsão, e quando o caboclo correu para socorrê-lo, verificou que ele jogava sangue pela boca. O índio, desesperado em ver aquele quadro trágico, pegou-se à vítima e perguntou o que sentia, mas foi tarde porque ele não teve mais tempo de falar. A morte foi-lhe fulminante.

Passado aquele momento de aflição, o caboclo dirigiu-se à casa dos vizinhos e comunicou o que [se] passou em sua casa. Incontinenti o Sr. Barcellos, professor daquele lugarejo, acompanhado de outras pessoas, dirigiram-se para a casa do índio a fim de procederem ao enterramento e fazerem o espólio do inditoso professor. ${ }^{44}$

O ticuna Nino Ataíde também teria afirmado “[...] que presenciou os regionais, que reuniram o espólio do cientista, conferir[am] em dinheiro a quantia de 30 mil cruzeiros, os quais, juntamente com outros objetos referidos, não foram arrolados no espólio", levando Manoelão a sugerir que para o desvendamento deste caso seria necessário que uma pessoa fosse in locco esclarecer as dúvidas (Pacheco de Oliveira 1986:265). 
Com base no relatório enviado por Manoelão, o inspetor Jacobina decide encarregar Nunes Pereira de conduzir uma investigação secreta sobre o caso e de recolher o espólio deixado por Curt Nimuendajú em campo.

Nunes Pereira chegou a Tabatinga no dia 06 de fevereiro, sendo apresentado às autoridades locais como "etnólogo e historiador" em viagem de pesquisa (Pacheco de Oliveira 1986:265), e já no dia seguinte escreveu ao inspetor Jacobina afirmando que tanto o mestre André Tomasi, que acompanhou Nimuendajú na viagem de Manaus a São Paulo de Olivença, quanto diversos índios "confirmam a versão do envenenamento" (Nunes Pereira para Jacobina, 07/02/1946). Uma semana depois escreveu outra carta na qual conta que outras pessoas, como o padre Manuel Albuquerque, o Sr. Waldemar Marco (médico do Sesp) e o índio Ponciano, também "falavam sempre em assassínio" (Nunes Pereira para Jacobina 13/02/1946). Ao fim de sua investigação, Nunes Pereira sugere ao inspetor Jacobina "que se proceda à exumação do cadáver de Curt Nimuendajú", tendo em vista que a partir de "declarações de pessoas idôneas" havia chegado à conclusão de que Curt Nimuendajú fora envenenado. ${ }^{45} \mathrm{O}$ relatório de suas investigações, porém, nunca apareceu (Pacheco de Oliveira 1986:266), e suas declarações sobre o caso são carentes de clareza, como veremos mais à frente. ${ }^{46}$

Em julho daquele mesmo ano, em uma entrevista ao jornal Folha do Norte, Nunes Pereira mencionou o "pressentimento de desgraça" que acometia Curt Nimuendajú, explicando que ele era estimado pelos índios, mas não pelos "civilizados", entre os quais os alemães que moravam nas margens do Solimões e que já teriam tramado sua prisão em 1942:

Em fins de novembro esteve comigo em Manaus o etnólogo Curt Nimuendajú, incumbido pelo Museu Nacional de completar seus trabalhos acerca dos índios Ticuna, do Solimões, nas fronteiras do Brasil com o Peru e a Colômbia. Estranhei logo que me disse só haver aceitado essa incumbência para atender à exigência da diretoria daquele Museu [Nacional], pois tinha pressentimentos de desgraça (Nunes Pereira 1946a).

Mas ele também declara que "Curt Nimuendajú já vinha há muitos anos fazendo estudos no campo da sexologia indígena" e sugere que a "delicadeza" dessas pesquisas tenha se colocado "contra algumas concepções dos Tukuna".

Acredito, porém, que a origem destes [receios de homicídio] seria a delicadeza de certas pesquisas, colocando[-se] talvez em choque [com] algumas concepções dos Ticuna. Curt Nimuendajú há muitos anos já vinha fazendo estudos 
no campo da sexologia indígena, havendo coletado mais de trezentas peças de literatura oral de várias tribos do Brasil que seriam publicadas sob o título "As trezentas", naturalmente antecedid[as] de um ensaio sobre a matéria, rico em notas e comentários. Mostrando-lhe a minha coletânea de histórias altamente obscenas, colhidas entre os Parintintin, Curt Nimuendajú se referiu à vida sexual dos Ticuna, entre os quais, dizia Tessmann, havia a prática da circuncisão para os dois sexos (Nunes Pereira 1946a).

Por fim, acrescenta que as informações recolhidas na feliz diligência projetavam certa claridade sobre esses estudos, e insinua que o assassino tenha se apropriado do respectivo manuscrito.

\begin{abstract}
Entre os seus papéis existem decerto elementos esclarecedores no tocante a esses estudos; admito, porém, que quem o matou tenha sequestrado a porção mais importante dos estudos de Curt no campo sexológico. A obra "Os Tukuna" foi demoradamente lida, e as suas páginas, principalmente as que registram qualquer assunto ligado à religião católica ensinada por padres nas missões dos altos rios, foram comentadas e sublinhadas grosseiramente, o que me levou a apresentar um protesto em juízo, visto que esse gesto criminoso pretendeu atingir, de um só golpe, um homem de ciência e a sua obra. [...] Acredito que o diário está incompleto, desfalcado por mão criminosa das suas melhores páginas, possivelmente. ${ }^{47}$
\end{abstract}

Pouco depois desta reportagem, Gama Malcher escreveu para Heloisa A. Torres acusando o recebimento do espólio de Curt Nimuendajú, que viera de São Paulo de Olivença: livros e notas sobre os Ticuna além de documentos, cartas e um diário (!). Além disso, Malcher informa sobre "o achado que Nunes Pereira fez de umas notas escritas a máquina, datadas em alemão, e que por sua livre recreação intitulou de 'diário erótico', atribuindo a paternidade de tudo ao Curt". De acordo com Malcher, Nunes Pereira, "que tão prontamente protestou contra a conspurcação da obra de Curt pelos frades, [...] levianamente tirou cópias do tal diário e espalhou a notícia entre seus amigos de bebedeira e cabotinagem superficialmente intelectual". ${ }^{48}$ Sobre a hipótese de assassinato levantada por Nunes Pereira, Malcher sugeriu que duas pessoas fossem ouvidas: o padre Manuel de Albuquerque, ${ }^{49}$ da Congregação do Espírito Santo, e Henrique Geissler, um dos alemães do igarapé da Rita, a quem Nunes Pereira recorreu para obter informações sobre a morte de Nimuendajú. ${ }^{50}$

Outra declaração de Nunes Pereira sobre o caso apareceu em seu livro Morongueta (1967), escrito quase 20 anos depois de sua investigação. Ali, ele menciona as descobertas de sua "especial diligência" e registra ter conseguido 
“[...] reaver algumas páginas (as da cópia), de um Diário Erótico, da autoria do cientista, cujo original não teria sido arrolado no espólio", além da monografia sobre os Ticuna, que teria sido rabiscada "por um padre leviano, crápula e sacrílego" (Nunes Pereira 1980 [1967]:448). ${ }^{51}$ Aqui ele também chama a atenção para a ausência de um diário de viagem que pudesse revelar suas últimas atividades: "[...] intriga-nos não termos encontrado entre os seus papéis, manuscritos e livros uma fonte, evidentemente preciosa, para a reconstituição das suas atividades antes do desfecho da sua existência" (Nunes Pereira 1980 [1967]:448). E promete a divulgação futura de um documento sobre o caso:

Noutra ocasião, em documento que pretendemos submeter à consideração pública, trataremos circunstancialmente da morte de Curt Nimuendajú, mas cumpre-nos esclarecer, desde logo, que todas as peças do espólio foram entregues ao juiz competente, em Belém do Pará, onde o cientista residia (Nunes Pereira 1980 [1967]:448).

Uma década mais tarde, em agosto de 1978, Nunes Pereira fez um novo depoimento sobre o caso, tornando pública a sua versão de assassinato e apontando Nino Ataíde como o autor do crime. Mas ao final insinuou que nisto haveria o interesse dos vizinhos civilizados, entre os quais os alemães:

Ele foi assassinado, e eu tenho receio que me mandem matar amanhã em alguma viagem pela Amazônia. Foi assassinado no igarapé da Rita, no município de São Paulo de Olivença, no Amazonas, [...]: Curt era um pansexual. Ele se hospedava na casa do Tuxaua Nino Evenique dos Ticuna. Ele deflorou uma filha do Tuxaua e mais uma sobrinha e prometeu casar-se com as duas. Mas nesta ocasião Curt foi preso como espião e levado para Manaus. [...]. Passado um ano, recebeu permissão de voltar à selva. Chegou à aldeia de Nino, hospedou-se de manhã. Deram-lhe veneno, e à tarde ele estava morto. Quem lhe ministrou veneno no caxiri foi Nino, porque Curt não havia cumprido a promessa que fizera de casar-se com sua filha e com sua sobrinha. Ele havia violado involuntariamente o código de honra dos índios. No igarapé da Rita havia uns alemães que exploravam a região, e que não gostavam de Curt Nimuendajú. Quando Curt chegava, os índios ficavam-lhe em torno e abandonavam os trabalhos na propriedade dos alemães. Era, para os proprietários da terra, uma presença importuna, você compreende? (Nunes Pereira 1978:11).

Quando perguntado sobre o "famoso diário erótico" de Curt Nimuendajú, sua resposta volta-se para o conturbado destino do espólio, contradizendo o que havia registrado em seu livro Moronguetá (1967). 
O diário de Curt não se achava relacionado entre os objetos de seu espólio, que entreguei ao Malcher, que era inspetor do SPI. Eu o consegui resgatar das mãos de terceiros. Havia interesse de algumas pessoas em ocultar o diário, que apareceu sem algumas páginas. Eu o entreguei a D. Heloisa Alberto Torres e hoje deve estar na posse da família dela, lá em Itaboraí (Nunes Pereira 1978:11-12). ${ }^{52}$

Heloisa Alberto Torres, que havia falecido cerca de um ano antes desta entrevista, nunca tratou publicamente do assunto, e seu acervo (Centro Cultura Heloisa Alberto Torres) não registra a existência de tal documento. Mas aí encontramos a fotocópia de uma carta valiosa, que nos permite melhor compreensão das enunciações enigmáticas de Nunes Pereira. Trata-se de uma carta enviada por Henrique Geissler, aquele alemão morador de Santa Rita, a Nunes Pereira, alguns meses após a sua investigação secreta:

Aviso que nesta data acabo de entregar sua máquina fotográfica ao Sr. Alcides Câmara [prefeito de São Paulo de Olivença], conforme havíamos combinado. Estranhei sua insistência em querer recebê-la a todo [ilegível] mesmo sem fotos e sem ter me remetido os filmes que tão solenemente prometeu em presença do Sr. Câmara! E a remessa dos volumes do "Kosmos", dos quais ainda estou na expectativa? Remeti há um mês e tanto um filme com fotos de minha gente acompanhada por carta, na qual pedia que mandasse revelá-los. Certamente nisso também, como nos outros assuntos, não serei atendido. O Sr. Roberto Backsmann [morador da vila de Santa Rita] ainda está à espera do material para a sepultura do Curt. Eu espero mas é sentado o envio de frascos - formol e naftalina - para conservação de insetos e batráquios, conforme fora combinado. Está-me a parecer que o amigo, com suas múltiplas promessas, só me queria "amaciar", temendo que eu, conjuntamente com o padre Manuel, desferisse algum golpe contra o prestígio científico de C.N., divulgando as mazelas morais do dito cujo, mazelas das quais eu tenho provas fotoestáticas, depositadas em dois países estrangeiros e no Brasil, portanto, três depósitos em mãos idôneas, e estes depositários só esperam um sinal meu, ou a notícia de alguma perseguição contra mim movida, para publicar na imprensa nacional e mundial (USA) as ocorrências havidas. Essa divulgação naturalmente não atingiria somente o prestígio do C.N. senão também o pretenso prestígio de cientistas, doutores e pseudocientistas que enxameiam por estes vastos Brasis. ${ }^{53}$

Considerando a documentação existente na Coleção Nunes Pereira da Biblioteca Nacional, esta carta encerra um conjunto de seis missivas, o que nos permite concluir que Henrique Geissler era o detentor do "diário erótico" e também o responsável pelo envio das cópias das páginas do diário 
("narrativas em alemão", conforme carta de Henrique para Nunes Pereira, 15/05/1946). Elas também lançam luz sobre as declarações confusas de Nunes Pereira acerca do diário, e das pesquisas na área da "sexologia" que estariam sendo levadas a cabo por Nimuendajú. Mas não nos permite concluir nada de novo sobre as circunstâncias de sua morte e as verdadeiras razões que levaram Henrique Geissler a preservar os manuscritos de Nimuendajú. Para isso, recorreremos aos depoimentos de Ricardo Geissler (1926-2008), filho de Henrique, e alguns artigos da imprensa teuto-brasileira.

\section{Do envenenamento à "tiragem" dos ossos}

Em fevereiro de 1956, com o pretexto de proporcionar um enterro digno ao compatriota, Herbert Baldus encarregou Harald Schultz de recolher os restos mortais de Curt Nimuendajú. É provável, no entanto, que o verdadeiro motivo fosse o desejo de averiguar a veracidade das versões até então aventadas para a morte do pesquisador, incluindo aquela publicada por Erich Keil nas revistas Südamerika e Die Auslese (1954), que acusava os alemães da vila de Santa Rita pela morte de Nimuendajú (Brasil Post, 12/02/55), o que certamente não passou despercebido por Baldus, um assíduo leitor da imprensa alemã. ${ }^{54}$

A exumação dos restos mortais foi realizada em 19 de fevereiro de 1956, na presença do delegado geral da Polícia de São Paulo de Olivença, do escrivão, e dos "peritos notificados" - o já mencionado Henrique Geissler e Roberto Backsmann, outro teuto-brasileiro da vila de Santa Rita - além das testemunhas Ricardo Geissler, Arlinda Backsmann e Antônio Lopes. Este último foi intimado a identificar o local em que o corpo fora sepultado e, junto com Ricardo, foi responsável pela abertura da sepultura, que conforme constatado havia sido invadida por um "lençol de água". De acordo com o oficio do cartório de São Paulo de Olivença, os restos mortais encontrados constavam de: "calota craniana, dois fêmur, massa encefálica apresentando sólida consistência, uma gravata e um par de botinas" (apud Hartmann 1981/82:188).

Os restos mortais de Curt foram levados por Harald Schultz para o Museu Paulista, onde ficaram por mais de 20 anos depositados numa igaçaba encomendada pela Sociedade Brasileira de Sociologia, até ser finalmente sepultado em 1981, "sem cerimônias, sem discurso nem solenidade" (Hartmann 1981/82:190).

Após a exumação dos restos mortais, um terceiro relato sobre sua morte veio à tona, mas ficou restrito aos leitores de alemão, pois foi publicado no jornal Brasil Post. Trata-se de um texto do padre Carlos Borromeu Ebner (mis- 
sionário da prelazia do Xingu, São Braz), que reproduz o depoimento de um "observador local" (anônimo) sobre as últimas horas de Curt Nimuendajú:

Na manhã do dia 10 de dezembro de 1945, um barco cheio de gente parou no porto de minha casa no rio Solimões. Dali saíram alguns índios que me eram conhecidos e o senhor Nimuendajú, que há poucos dias havido chegado em São Paulo de Olivença, vindo de Manaus.

Nimuendajú me causou uma impressão saudável e os índios pareciam bastante satisfeitos. Tinha, porém, muita pressa, e não se demorou demais. Depois que saiu da minha casa provavelmente seguiu sem fazer paradas até o seu destino final, isto é, a maloca do igarapé da Rita. Nessa distância um barco a remo leva umas quatro horas. Ali, naquela maloca, onde ele se deitou para dormir logo após a sua chegada, ele morreu subitamente (Ebner 1958, tradução minha).

De acordo com o depoimento deste "observador", os índios teriam imediatamente seguido até a Vila de Santa Rita a fim de notificar as autoridades:

Por volta das 8 horas da tarde uma canoa lotada parou no meu porto. Um dos remadores gritava: "Aconteceu algo terrível, Nimuendajú teve uma súbita hemorragia e está morto". Os índios disseram: "Nimuendajú bebeu uma garapa, teve uma convulsão hemorrágica, caiu e morreu". Estranho, que ninguém se lembrou de analisar ou levar a embalagem utilizada. Em vez disso, eles se ocuparam em mexer e fuxicar nas malas do falecido (apud Ebner 1958, tradução minha).

Ainda de acordo com o relato deste observador, no dia 11 de dezembro o corpo "finalmente" chegou a Santa Rita, sendo trazido por seus companheiros, que o deixaram para ser velado na escola. O observador teria ido então ver o cadáver e constatou que ele estava vestido com um bom e limpo terno e tinha a barba feita. Mas a boca estava suja de sangue, que parecia ter vindo dos pulmões - "pois era claro e espumoso" - e o corpo tinha uma cor feia, "roxo", "quase azul", e parecia inchar de minuto a minuto. Convencido de que Nimuendajú tinha sido vítima de um envenenamento, o observador contou que insistiu na necessidade de uma autópsia e, com ajuda de um "arigó", procurou despir o cadáver a fim de constatar se havia algum ferimento externo, mas não conseguiu fazer isto completamente, pois o corpo já estava enrijecido.

Convicto de que a morte havia sido provocada, o observador teria ainda pensado em coletar uma amostra de sangue que pudesse ser posteriormente analisada. Procurou por um pano que servisse para este fim, mas como ninguém dali lhe disponibilizou o material, o observador foi pegá-lo 
em sua casa e, quando voltou pouco tempo depois, o corpo já havia sido enterrado. Por fim, o observador sugere que o enterro tenha sido acelerado com a intenção de esconder o corpo que parecia que ia explodir, e chama a atenção para o fato de que das três malas trazidas por Nimuendajú, apenas duas foram encontradas.

Não foi possível descobrir o autor do relato, nem mesmo as condições em que Ebner o ouviu, mas, em razão da data, podemos presumir que seja oriundo das apurações feitas por Harald Schultz junto a algum dos alemães que não acompanharam o velório na maloca ticuna, possivelmente da família Weil-Müller.

Nos dias de hoje as lembranças mais significativas que os antigos moradores de Santa Rita têm de Curt Nimuendajú vagueiam sobre este momento da exumação, e são curiosamente precisas no que se refere aos despojos encontrados dentro do caixão: o "miolo", os ossos da perna, as botas e a gravata.

O senhor Nicanor de Almeida (1936) lembrou-se do dia em que Henrique Geissler trouxe o caixão de Curt Nimuendajú para Santa Rita, registrando a versão de que teria sido envenenado pelos Ticuna. Na sua opinião, porém, havia um segredo por trás deste veneno, ou mais especificamente, um diário:

Eu tinha um amigo aqui, nessa casa onde nós estamos, que o nome dele era Ricardo, o qual me contava umas histórias de um antropólogo chamado Curt... ele tinha um diário que mesmo o pai do Ricardo tinha vergonha que fosse descoberto aquilo, porque na nossa linguagem aquilo era um segredo, ninguém podia saber [...] antes ainda vieram atrás disso, mas ele não se encontrava com coragem de entregar, para não ser publicado [...]. Ele [Ricardo] não me contou, ele só me contou, assim, que tudo que ele [Curt] fazia com as indiazinhas ele anotava, esse negócio de namoro, essas coisas... aqueles cabelinhos bonitos, essas coisas...55

José de Almeida (1948), outro morador de Santa Rita, também registrou a suspeita de que Nimuendajú foi envenenado pelos índios, e lembra-se com detalhes do dia da exumação, quando o "irmão" de Curt - um alemão alto, "fortão" - veio pegar os restos mortais no cemitério: ele teria ficado na casa de seu avô Salustiano por uns três dias, e depois viajado "para a Alemanha":

[...] quando o irmão do finado Curt chegou aqui, eu assisti a tiragem dos restos mortais dele... daqui do cemitério de Santa Rita. O irmão dele chegou aqui na casa do meu avô, passou três dias, nesses três dias ele fez o trabalho com o pessoal daqui e tirou os ossos dele, colocou numa caixa e no quarto dia ele 
baixou para Manaus, levando esse material, e ia pegar o avião para viajar para a Alemanha, para ser[em] sepultado[s] lá os restos mortais dele [...] Naquele tempo tudo era assim fechado... mas eu vi tudinho na casa do meu avô: os ossos, o miolo dele, o cabelo, e uma gravata, uma gravata que nunca acabou, tudo isso eu assisti, muitas pessoas viram... e aí ele [Harald Schultz] levou, dizendo que era irmão dele, que ia buscar, que tinha morrido envenenado... Os Ticuna disseram que ele morreu envenenado, com uma bebida de banana madura chamada pororoca, ele bebeu. Mas parece que os Ticuna estavam com raiva dele, porque ele estava andando em toda a comunidade indígena e deram veneno para ele, assim me contavam, que os próprios Ticuna que contava[m] [...] A gente fica naquela admiração, né? Quem foi, né? Se contam... ${ }^{56}$

Ao contrário do observador anônimo, que sugere o envolvimento de não indígenas na morte de Nimuendajú, os relatos dos moradores de Santa Rita reproduzem a versão que responsabiliza os Ticuna. Todas, porém, chamam a atenção para um importante detalhe evidenciado pela exumação: a conservação das botas e da gravata.

Conforme me parece, a evidência de que o cadáver estava vestindo botas e gravata se encaixa diretamente no contexto de morte informado pela primeira versão de Nino Ataíde, isto é, de que Nimuendajú teria morrido quando voltava de uma visita a um "civilizado". Para considerarmos a versão dos não indígenas (iniciada por Barcellos), na qual Curt Nimuendajú teria morrido enquanto se preparava para dormir, devemos presumir que o cadáver teria sido "arrumado" para o enterro, o que explicaria as botas e a gravata no lugar de uma confortável roupa de dormir.

Neste caso, porém, apenas poderíamos esperar isso dos moradores da vila de Santa Rita, que primeiro deram assistência ao cadáver na maloca de Nino Ataíde, isto é, os Barcellos e Henrique Geissler. Mas um último depoimento que temos sobre a morte de Nimuendajú não corrobora esta hipótese, e ele foi dado justamente por Ricardo Geissler, filho de Henrique. ${ }^{57} \mathrm{Na}$ versão de Ricardo, apresentada como uma repetição do que lhe fora narrado por seu pai, quando este chegou à maloca de Nino Ataíde, o cadáver de Curt Nimuendajú já estava "todo vestido".

De acordo com o depoimento de Ricardo Geissler, Curt Nimuendajú teria morrido no "igarapé do finado Barcellos" logo após sua chegada à maloca de Nino, quando se preparava para dormir. Seu pai foi comunicado por Barcellos, que apareceu numa canoa no porto de sua casa por volta das 10 horas da noite. Henrique teria se surpreendido com a notícia, pois algumas horas antes Nimuendajú teria passado por seu porto e avisado que voltaria no dia seguinte para entregar-lhe algumas encomendas: "Já morreu?", disse 
ele a Barcellos, "já morreu", respondeu este. Junto com Júlio Pinto, outro civilizado de Santa Rita, Henrique seguiu para a maloca de Nino, onde encontrou o cadáver vestido. Ricardo contou que seu pai, ciente dos presentes que receberia de Nimuendajú, iniciou o exame dos bens deixados pelo falecido, anotando e distribuindo tudo o que era encontrado. Acharam um pacote com 30 mil cruzeiros e, com esse dinheiro, compraram tábuas para o caixão e pagaram coveiro, sobrando deste valor uma quantia significativa. Havia também a máquina fotográfica, que mais tarde foi entregue ao juiz de São Paulo de Olivença, e os manuscritos de Nimuendajú, que foram levados por Henrique, o único que entendia "aquela letra". Conforme Ricardo, o diário não apenas continha a descrição das aventuras eróticas de Nimuendajú, mas também uma coleção de pelos pubianos, que eram cuidadosamente guardados em folhas nomeadas.

Quando Nunes Pereira fez a sua investigação em fevereiro de 1946, ele chegou rapidamente a esta informação e conseguiu assim recuperar a "monografia Ticuna" e as cartas. Mas o diário continuou com Henrique, que apenas fez menção ao seu conteúdo e aceitou copiar algumas páginas do mesmo, aparentemente em troca de um incentivo material para as suas atividades colecionadoras. Nunes Pereira teria ainda deixado uma máquina fotográfica com Henrique (talvez a do próprio Nimuendajú?), incumbindo-o de tirar fotos das "caboclinhas" do igarapé da Rita, mas a máquina fotográfica foi devolvida sem uso ${ }^{58}$. Assim contou Ricardo sobre o encontro de seu pai Henrique e Nunes Pereira:

Aí meu pai foi, juntou tudinho, traduziu para o português uma parte e quando foi com dois meses, veio o Dr. Nunes Pereira do Rio e chegou lá em casa:

"Aqui que mora o Henrique?"

"Sou eu patrício!"

"Olá! Eu vim aqui pra você entregar o espólio, quer dizer, o diário de Curt Nimuendajú!"

"Negativo, não entrego não!"

"Ah! Você não entrega?! Mas você tem!"

"Não entrego porque eu fico envergonhado do meu patrício fazer o que ele fez..." "Quer dizer que você não vai mandar publicar?" - Estava com medo que papai mandasse publicar.

"Não!" - papai disse.

"Ah! Então, tá bem."

"Tá bem..."

Ele queria pegar para meu pai não publicar. Bem, aí papai contou para ele o que tinha e ele disse: 
“Bem, então vamos fazer o seguinte, vou deixar uma máquina fotográfica para você tirar umas fotos das caboclinhas", e foi embora. ${ }^{59}$

Ainda de acordo com Ricardo, Henrique teria dado uma "parte" do diário para seu sobrinho Gunther Hipper, e uma fotografia para o padre Manuel. O resto teria sido destruído num incêndio provocado em sua casa pelos índios ticuna na década de 50. Alguns anos após esse incêndio, Henrique recebeu a visita de três pessoas de Brasília que também procuravam pelo diário. Como o diário já não existia mais, eles pretenderam gravar um depoimento, mas o equipamento de áudio não funcionou e eles se ocuparam então de fotografar o timbó que teria sido usado para envenenar Curt Nimuendajú. Ricardo não se lembrou dos nomes dessas pessoas, mas a data e outros detalhes da sua descrição nos levam a identificá-las como pertencentes à equipe de pesquisa de Roberto Cardoso de Oliveira que, composta por Ivan Lowie (linguista do Summer Institute of Linguistics) e pelo jornalista e fotógrafo Maurício Vinhas de Queirós, tinha o objetivo de estudar a produção do curare na região (Fürbringer 2012).

Uma passagem do diário de Roberto Cardoso de Oliveira (19/04/1959) nos permite reconstituir esse momento em que ele inicia "a viagem de pesquisa etnológica nos igarapés de Takana e Belém", a bordo do barco Caldeirão, que pertencia ao patrão Antônio Roberto Aires de Almeida e era guiado por seus filhos:

Somos três: Doutor Ivan Lowie, linguista do Summer Institut of Linguistics, que se ofereceu a nos acompanhar para estudar o idioma Tukuna, o jornalista e fotógrafo Maurício Vinhas de Queirós, meu amigo e companheiro no grupo de estudos sobre o pensamento de Marx, grupo, aliás, que vem se reunindo em sua casa quinzenalmente, e eu, que estou passando da etnografia dos Terêna para a dos Tukuna, inspirado em Curt Nimuendajú, morto há cerca de quinze anos nesta região em circunstâncias misteriosas (Mendonça 2000:194).

Inspirado pela experiência etnográfica de Nimuendajú, Cardoso de Oliveira visitou Calixto, um dos principais informantes daquele pesquisador, "um homem dos seus 60 anos, de olhos claros, como a confirmar a lenda de sua origem, filho de pai alemão, como, aliás, ele mesmo me declarou" (Cardoso de Oliveira apud Mendonça 2000:202), e depois disso seguiu com José Roberto (filho do patrão Antônio Roberto Aires) subindo o igarapé "Caldeirão".

Três anos depois, em julho de 1962, Roberto Cardoso de Oliveira voltou ao Solimões acompanhado dessa vez de seus assistentes Cecília Maria Vieira 
Helm e Silvio Coelho dos Santos, que fez um bom registro fotográfico da viagem. Dos dados colhidos nestas duas etapas de pesquisa de campo (1959 e 1962) resultou o livro O índio e o Mundo dos Brancos (1964).

\section{Conclusão}

Apesar de Curt Nimuendajú ser muitas vezes referido como um dos fundadores da etnologia brasileira, ou pelo menos como o pesquisador que mais conhecimento produziu sobre as populações indígenas do Brasil, na história desta disciplina ele figura como um personagem marginal e excêntrico, assim caracterizado por negativas, isto é, não tinha formação universitária, não foi funcionário de instituições acadêmicas, não possuía uma orientação teórica definida e não formou escolas de pensamento (Melatti 1985; Cardoso de Oliveira 1996 [1964]).

Contribuiu para isso a trajetória autodidata de Curt Nimuendajú e a sua reincidente recusa em assumir posições ou cátedras acadêmicas, além da inexpressiva contribuição teórica de seus escritos. Algo, porém, sugere que as suspeitas que recaíram sobre as causas de sua morte e, depois, sobre a existência de um comprometedor "diário erótico" também tenham contribuído para essa "marginalização".

Um exame mais profundo de sua trajetória indica que esta "marginalidade" foi postumamente atribuída a Nimuendajú, que até então era considerado pelos principais americanistas de seu tempo como o mais importante pesquisador dos índios do Brasil, tendo exercido uma grande influência na formação da primeira geração de etnólogos deste país, em especial os do Museu Nacional, que acabou por adquirir seu espólio.

A proposta de compra do espólio foi feita à viúva Jovelina por intermédio de Gama Malcher, que passaria a ser o mediador dessa comunicação que envolvia, de um lado, a humilde cabocla e, de outro, a cientista carioca Heloisa Alberto Torres. Em janeiro de 1946, Jovelina aceitou a proposta que aparentemente não incluía valores ${ }^{60}$ mas dali até outubro daquele ano o negócio em nada avançou, pois Heloisa alegava não ter dinheiro para adiantar à viúva como parte do pagamento e cobrava a realização de um arrolamento do espólio que permitisse uma avaliação do material ${ }^{61}$ Por fim, o espólio foi avaliado em 90 mil cruzeiros e, em fevereiro de 1951, Jovelina finalmente recebeu o pagamento, que veio descontado do valor referente à "mesada" de 1.000 cruzeiros que recebeu de Malcher desde dezembro de 1947, isto é, pouco mais de 54 mil. ${ }^{62}$ 
Durante todo esse período foram muitas as solicitações de acesso aos manuscritos do espólio. Do Museu Paulista, por exemplo, vieram tentativas de compra e publicação dos manuscritos, empreendidas por Herbert Baldus e Sergio Buarque de Holanda, mas todas foram em vão. ${ }^{63}$ Nunes Pereira, por sua vez, que se dizia um dos melhores conhecedores da obra de Nimuendajú, cobrava a publicação dos manuscritos, denunciando a situação de miséria de Jovelina na imprensa do Pará e do Rio de Janeiro. ${ }^{64}$

Após a chegada do espólio ao Museu Nacional, deu-se o seu desmembramento, cujas partes foram alocadas em diferentes setores da instituição: livros com dedicatórias e anotações do próprio Nimuendajú foram incluídos no acervo da biblioteca, enquanto seus manuscritos, separados segundo sua natureza "linguística" ou "etnográfica", foram depositados em arquivos distintos. A este último foi reunido o material recolhido por Nunes Pereira em Santa Rita.

No acervo etnográfico ficaram a última versão da monografia Timbira e uma coletânea de mitos indígenas, além dos diários de campo, entre os quais os das viagens aos Ticuna nos anos de 1941 e 1942 que, apesar de muito danificados, revelam a intimidade erótica de Nimuendajú entre estes índios (Welper 2002).

Como diretora do Museu Nacional, Heloisa A. Torres teve grande influência no destino de sua obra e memória. Sabemos que ela foi privilegiadamente informada acerca da investigação de Nunes Pereira - que resultou na ameaça de Henrique Geissler. O conteúdo erótico desses outros diários de Nimuendajú só veio reforçar as versões daqueles dois, isto é, que Nimuendajú mantinha relações com as filhas de Nino Ataíde e que o seu último diário estava em mãos alheias, muito provavelmente nas de Henrique Geissler, que já mostrava a intenção de divulgar publicamente as "mazelas morais" de Nimuendajú, caso se sentisse ameaçado.

É provável que naquele contexto formativo da antropologia brasileira a falta de uma investigação sobre a morte de Curt Nimuendajú e a não publicação de seus manuscritos resultassem do receio sobre as consequências políticas de atrelar o nome de uma das maiores instituições científicas do país a um pesquisador que a qualquer momento poderia ser "desmascarado" por um diário erótico que exporia uma intimidade senão moralmente condenável, cientificamente criticável. ${ }^{65}$ Por mais que a ameaça de Henrique Geissler de certa forma absolvesse os índios do crime, a verdade dos fatos poderia expor Curt Nimuendajú e, junto com ele, o Museu Nacional a um julgamento moral que não apenas atingiria sua pessoa (como homem casado), mas também a imagem científica dos antropólogos daquela instituição que começavam a desbravar o Brasil. É importante lembrar aqui que Nimuendajú 
era a referência para qualquer trabalho etnológico e que, por sua expertise etnográfica, já era solicitado por Heloisa A. Torres para dar uma orientação informal aos alunos novos do Museu Nacional que se dirigiam a campo.

E aqui voltamos à primeira parte deste texto na qual acenei para a contribuição que o debate sobre a subjetividade erótica no trabalho de campo poderia trazer para uma melhor compreensão do caso Nimuendajú.

A associação entre sexualidade e encontros etnográficos não é nova. A aproximação entre o exótico e o erótico, seja ele perverso, excessivo, ou romântico, tem sido profundamente manifestada pela arte e a literatura, e o campo da etnografia de certa forma foi alimentado por tais imagens e emoções (Kulick 1996). Nos romances de aventura western - um dos gêneros mais populares da literatura alemã no último quartel do século XIX, e que tanto influenciou o autodidata Nimuendajú (Welper 2013) - os autores descreveram jornadas de desbravamento de territórios indígenas, perseguições e captura de civilizados, mas, sobretudo, insinuaram a possibilidade de amizade sincera e amor verdadeiro entre brancos e peles vermelhas (Cracroft 1987:160).

Apenas a formalização do trabalho de campo e, depois, da observação participante trouxe a demanda de um etnógrafo assexuado, orientado a encobrir desejos e identidades sexuais durante este trabalho (Kulick \& Wilson 1996). Nisto, primeiro existiu o legado boasiano de uma antropologia tutelar, na qual o registro etnográfico fazia parte de um projeto salvacionista que, a fim de garantir uma inscrição correta das várias culturas em extinção, suprimia as subjetividades dos antropólogos em prol de uma equivalência metodológica. E depois a herança de Malinowski, que formalizou a "observação participante" como principal ferramenta da antropologia, e uma espécie de self negation como pré-requisito metodológico - conveniente num contexto colonial, pois eximia os etnólogos de tomar posições diante dos conflitos entre nativos e europeus (Markowitz \& Ashkenazi 1999).

A publicação do diário de Malinowski, recheado de narrativas de sonhos, emoções e sentimentos cotidianos, foi muito importante para quebrar essa instância objetivista e self confident da antropologia, mas não avançou sobre a questão da subjetividade erótica do etnógrafo e seus nativos, permanecendo um tipo de regra (não escrita) sobre a ética sexual em trabalho de campo, a qual poderia ser resumida em uma única mensagem: "Não faça!" (Kulick \& Wilson 1996:10).

Torna-se assim compreensível que as evidências sobre a praxis etnográfica de Curt Nimuendajú, trazidas à tona por ocasião de sua morte, tenham levado a uma reavaliação do seu "fazer etnográfico", que antes era reconhecido e valorizado pelo seu caráter científico. Como efeito, Curt 
Nimuendajú foi homenageado de várias formas, recebeu placa e escultura em Belém, pedra em Jena (sua cidade Natal); deu nome ao antigo Posto Indígena Araribá, mas também a uma rua da cidade de São Paulo, a uma sala do MAE, à biblioteca da Funai e a uma editora de Campinas. No Museu Nacional, porém, por onde circulou a versão informal e didática “[...] de que Nimuendajú teria sido morto pelos próprios índios, como represália por um relacionamento sexual com mulheres do grupo" (Pacheco de Oliveira 1986:267), seus manuscritos continuaram inéditos e seu nome não consta nem na sala que abriga seu arquivo.

Recebido em 12 de fevereiro de 2016

Aprovado em 06 de junho de 2016

Elena Welper é pós-doutoranda do Programa de Pós-graduação em Antropologia Social, Museu Nacional, Universidade Federal do Rio de Janeiro, Rio de Janeiro/RJ, Brasil. E-mail: <elenawelper@yahoo.com.br>

\section{Notas}

1 Este artigo foi produzido no âmbito da pesquisa de pós-doutorado "Da moderne ethnologie a etnologia moderna: Curt Nimuendajú e a tradição germânica nas terras baixas da América do Sul", financiada pelo PAPD da Faperj.

2 Além do Arquivo Curt Nimuendajú (ACN), foram consultados os acervos documentais das seguintes instituições: Biblioteca Nacional (BN), Centro de Cultura Heloísa Alberto Torres (CCHAT) e Museu de Astronomia e Ciências Afins (MAST). Os depoimentos foram coletados nas cidades de Tabatinga, Benjamin Constant, São Paulo de Olivença e em Santa Rita do Weil, entre agosto e setembro de 2014.

3 Carta Nimuendajú para H. Baldus, 01/12/1940 (ACN, tradução minha).

4 Carta Nimuendajú para R. Lowie, 04/11/1940 (ACN, tradução minha).

5 Carta R. Lowie para Nimuendajú, 18/11/1940 (ACN, tradução minha).

6 Os Ticuna habitam o território de fronteira do Brasil com o Peru e a Colômbia e constituem a maior população indígena da região Amazônica (37 mil).

7 Relatório dos índios Ticuna (1929), publicado em 1977. 
8 "Besuch bei den Tukuna-Indianer [Visita aos índios Tukuna]" (1930), traduzido em 2013.

9 Tukuna Reise II -1941 (ACN).

10 Carta Nimuendajú para Quirino Mafra, 10/10/1941 (ACN).

11 Carta Nimuendajú para Nilo Müller, 24/01/1942 (ACN).

12 Carta Nino Ataíde para Nimuendajú, 09/02/1942 (ACN).

13 Carta Nimuendajú para Quirino Mafra, 24/01/1942 (ACN).

14 Tukuna Reise III, 1942, ACN.

15 Carta Nimuendajú para Heloisa A. Torres, 21/10/1942 (ACN).

16 Em 1973, em entrevista a Pacheco de Oliveira, Quirino Mafra “[...] mencionou lembrar-se de que 'no passado' um estrangeiro (que qualificou como 'amalucado') havia pretendido 'morar com os índios no alto dos igarapés', mas que ele não havia permitido. Dizia haver ficado desconfiado das boas intenções dessa pessoa, cujos interesses reais, explicava-me a partir daquele momento presente, deveria ser a 'agitação política' ou estar relacionada ao tráfico de drogas" (Pacheco de Oliveira 2013:251).

17 Carta Nimuendajú para Nino Ataíde, 21/11/1942 (ACN).

18 A primeira versão escrita em português foi concluída em junho de 1943.

19 Carta Nimuendajú para A. Metraux, 10/10/1943 (ACN).

20 Carta Nimuendajú para A. Metraux, 06/11/43 (ACN).

21 Carta Nimuendajú para Nino Ataíde, 08/10/1943 (ACN).

22 Henrique Geissler (1899-1967) foi um dos fundadores da vila de Santa Rita do Weil. Chegou aos 16 anos e logo se casou com uma índia cocama, com quem teve três filhos. Vivia na boca do igarapé da Rita onde possuía suas roças e destacava-se como um homem culto: sabia falar muitas línguas e gostava de ler revistas científicas, como a Kosmos. Por sua boa caligrafia era solicitado a prestar favores e serviços desse gênero.

23 De acordo com o Almanak Administrativo, Mercantil e Industrial do Rio de Janeiro do ano de 1930, Pepo de Almeida Barcellos foi intendente e "adjunto de promotor" do município de São Paulo de Olivença (vol. III:216). Os Ticuna referem-se a ele como um professor. 
24 Carta Nimuendajú para Nilo Müller, 22/11/43 (ACN).

25 Carta Nimuendajú para Nino Ataíde, 03/01/1944 (ACN).

26 Frei Fidelis de Alviano foi o primeiro missionário capuchinho a atuar sistematicamente entre os Ticuna. Chegou ao Solimões em 1926, e quatro anos depois começou a desenvolver a catequese dos índios de Belém do Solimões (Hüttner 2007:70).

27 Nimuendajú para Nino Ataíde, 15/04/1944 (ACN).

28 Nimuendajú para Nilo Müller, 23/11/44 (ACN).

29 Nimuendajú para Nino Ataíde, 07/08/1945 (ACN).

30 Nimuendajú para Nino Ataíde, 26/09/1945 (ACN).

31 Nunes Pereira para Gama Malcher, 20/12/1945 (CCHAT).

32 Nunes Pereira para Gama Malcher, 20/12/1945 (CCHAT).

33 Tratava-se do fato de Curt Nimuendajú ter tomado conhecimento do armamento utilizado pelos funcionários do órgão para a ação de aproximação junto aos Parakanã.

34 As demais cartas foram escritas para Maynhutsen, Ayron Rodrigues e Herbert Baldus. Devo registrar que todas foram datadas do dia 07 de dezembro, mas aquela enviada para H. Schultz tem como local a "maloca Tukuna, ig. Rita" ao invés de São Paulo de Olivença.

35 Carta da agente telegráfica de São Paulo de Olivença, Clotilde Brito da Silva, para Jovelina Nimuendajú, 26/12/1945 (CCHAT).

36 Carta de Pepo de Almeida para Agnello Bittencourt, 15/2/1946 (Dossiê Curt Nimuendajú, MAST).

37 Carta de Pepo de Almeida para Agnello Bittencourt, 15/2/1946 (Dossiê Curt Nimuendajú, MAST).

38 Por esta razão, José M. Gama Malcher acabou intermediando a negociação de compra do espólio realizada entre Heloisa Alberto Torres, diretora do Museu Nacional, e Jovelina Nimuendajú.

39 Nunes Pereira (1893-1985) era veterinário e ictiólogo, e como tal foi funcionário do Instituto de Caça e Pesca do Ministério da Agricultura, em Manaus. De forma autodidata, realizou estudos etnográficos, entre os quais aquele sobre o 
Porantim, remo-mágico dos Maué, que foi assunto para a sua primeira conversa com Nimuendajú, ocorrida no Museu Goeldi (Nunes Pereira 1978:11).

40 Sinal disto foi o fato de ele não ter comunicado a morte de Nimuendajú à sua irmã Olga Richter que, após anos sem receber notícias do irmão, acabou por se desfazer de todas as cartas e fotos que tinha dele.

41 Nunes Pereira foi o responsável pela identificação e guarda dos restos mortais de Koch Grünberg (1872-1924) que, a pedido de Câmara Cascudo, foram transladados do local de seu sepultamento para o Instituto de Etnografia e Sociologia do Amazonas (Nunes Pereira 1978:10). Koch-Grünberg faleceu vitimado por uma malária, em Vista Alegre.

42 Nunes Pereira para Gama Malcher, 20/12/1945 (CCHAT).

43 Nunes Pereira para Gama Malcher, 20/12/1945 (CCHAT).

44 Carta de Manuelão para Jacobina, 16/01/1946 (CDE-MI, SPI Of. N.25: v)

45 Telegrama de Nunes Pereira para Jacobina, 22/02/1946 (CCHAT).

$46 \mathrm{Na}$ Coleção Nunes Pereira (BN) consta a informação de um relatório (17p.) relativo às investigações sobre a morte de Curt Nimuendajú, que teria sido enviado ao Dr. Alberto Pizarro Jacobina em anexo à carta de 20/03/1946, porém o mesmo não foi encontrado.

47 Nunes Pereira, Folha do Norte, 16/07/1946 (CCHAT).

48 Cabe aqui um registro pessoal feito por Bessa Freire acerca da personalidade de Nunes Pereira: "Lascivo e libidinoso, contava histórias surpreendentes e engraçadas, na roda de amigos e admiradores nos bares em que frequentava" (Bessa 2013).

49 Padre Manuel Rebouças Albuquerque (1907-1977) nasceu no município de Eirunepê (AM) e, depois de estudar no seminário de Teffé, foi para Portugal onde ingressou na Congregação do Espírito Santo. Ordenou-se padre em 1935 e em 1936 voltou ao Brasil para trabalhar no interior do Amazonas, Acre e Pará.

50 Carta de Gama Malcher para Heloisa A.Torres, 21/07/1946 (CCHAT).

51 Na verdade, não se tratava da monografia, mas de uma compilação de fichamentos da bibliografia Ticuna, intitulada Auszüge über die Tukuna [Extractos sobre os Ticuna].

52 Em 1984, um ano antes de sua morte, em entrevista a Mariza Correa, Nunes Pereira confirmou a versão de assassinato, mencionando a existência do diário erótico e explicando que Nimuendajú teria sido envenenado por "não voltar para honrar o 
compromisso com uma índia" (Correa 1985:334). De acordo com Pacheco de Oliveira, o fato de sua investigação ter sido realizada em convivência com os regionais explicaria por que "[...] ele acabou por encampar a versão de que Nimuendajú foi assassinado pelos ticunas" (Pacheco de Oliveira 2013:246).

53 Carta de Henrique Geissler para Nunes Pereira, São Paulo de Olivença, 05 /08/1946 (CCHAT).

54 Um depoimento colhido por Faulhaber junto ao ticuna Júlio Ramires, que conheceu Curt em Santa Rita de Weil, também aponta o envolvimento dos alemães, afirmando que ele "morreu de doença, provocada por alguém que tinha inveja dele". Segundo Júlio, "o alemão chamou o Curt, e deu uma xícara de café para ele". Após tomar o café, Curt saiu da casa de Nino para ir embarcar suas bagagens, dentro das quais carregava muitos presentes para os Ticuna. Chegando ao porto onde se encontrava a embarcação, Curt "ficou preto" e morreu (Faulhaber 2005). Esta autora também registrou o depoimento do ticuna Adolfo, de 83 anos que, comparando Curt a um professor, sugere que ele teria sido morto porque ajudava os Ticuna: "Ele trocava coisas, terçados, dava para as pessoas que não tinham nada, dava roupas, tudo. Depois o branco fez isso com ele. Não foi Ticuna porque Ticuna sabia que ele ajudava. Então o branco não gostava que ele ajudasse os Ticuna, aí o branco deu veneno para ele" (Faulhaber 2005). Pacheco de Oliveira registra que entre os moradores brancos de Santa Rita do Weil correu a versão de que "os índios teriam envenenado Nimuendajú para saquearem os seus pertences", mas o autor chama a atenção para o fato de que "os Ticuna não teriam motivos para saquear objetos que a eles seriam dados" (Pacheco de Oliveira 1986:272).

55 Depoimento Nicanor de Almeida, 25 de agosto 2014, Santa Rita do Weil.

56 Depoimento José de Almeida, 25 de agosto 2014, Santa Rita do Weil.

57 Entrevista de Ricardo Geissler, Santa Rita do Weil, 2002 (Acervo Pessoal Guido Revelo). Guido Revelo Calderón é neto de Henrique Geissler e, com muita generosidade, me disponibilizou algumas fotos de seus familiares e o áudio da entrevista que fez ao seu tio Ricardo Geissler. Quero aqui registrar meu agradecimento especial a ele.

58 Henrique Geissler para Nunes Pereira, 05/08/1946 (CNP-BN).

59 Ricardo Geissler, 2002 (acervo pessoal Guido Revelo).

60 Carta de Gama Malcher para Heloisa A. Torres, 27/12/1945 (CCHAT).

61 Heloisa A. Torres para Gama Malcher, 29/10/1946 (CCHAT).

62 Hilda Cabral Malcher para Heloisa A. Torres, 21/02/1951(CCHAT). 
63 Carta de Sergio Buarque de Holanda para Heloisa Alberto Torres, 19/11/1946, e carta de Herbert Baldus para Nunes Pereira, 04/11/1946 (CCHAT).

64 "Roubaram o patrimônio de Nimuendajú em Belém, e jogaram sua mulher numa tina de roupa suja", Folha Carioca, s/d (CCHAT).

65 Vale lembrar que poucos anos antes, em 1939, a comunidade antropológica já havia sido surpreendida com o suicídio de Buell Quain durante seu trabalho de campo entre os Krahô.

\section{Referências bibliográficas}

BESSA FREIRE, José Ribamar. 2013. "O colecionador de histórias". Taquiprati 01/12/2013. Disponível em:. http:// www.taquiprati.com.br/cronica/1062-o-colecionador-de-historias. Acesso em: 14/09/2016.

BENDAZZOLI, Sirlene. 2011. Políticas públicas de educação escolar indígena e a formação de professores ticunas no Alto Solimões/AM. Tese de Doutorado em Educação, Universidade de São Paulo - USP, São Paulo.

CARDODO DE OLIVEIRA, Roberto. 1996 [1964]. O índio e o mundo dos brancos. $4^{\mathrm{a}}$. ed. Campinas: Editora da Unicamp.

CORRÊA, Mariza. 1985. "O dono do trovão". Anuário Antropológico, 85:333-336.

CRACROFT, Richard H. 1987. "World westerns: the European writer and the American West". In: Western Literature Association (U.S.), A literary history of the American West. Fort Worth: Texas Christian University Press. pp. 159-179.

EBNER, Carlos B. 1958. "Um den tod der Kurt Unckel". Brasil-Post, SP, 15/03/1958.

FAULHABER, Priscila. 2005. "O etnógrafo e seus 'outros'; informantes ou detentores de conhecimento especializado?". Estudos Históricos 36:111-129.

FÜRBRINGER, Nádia Philippsen. 2012. "Fotografias, diários de campo e coleções etnográficas: novas articulações, apropriações e ressignificações". Tellus, 22:233-249.

HARTMANN, Thekla. 1981/1982 . "O enterro de Curt Nimuendajú (18831945)". Revista do Museu Paulista, 28:187-90.

HÜTTNER, E. 2007. A Igreja Católica e os povos indígenas no brasil. Os Ticuna da Amazônia. Porto Alegre: EDIPUCRS.

KULICK, Don \& WILSON, Margaret (eds.). 1996. Taboo: sex, identity and erotic subjectivity in anthropological fieldwork. London: Routledge.

KULICK, Don. 1996. "Introduction. The sexual life of anthropologists: erotic subjetivity and ethnographic work". In: Taboo: sex, identity and erotic subjectivity in anthropological fieldwork. London: Routledge. pp. 1-28.

LARAIA, Roque. 1988. "A morte e as mortes de Curt Nimuendajú". Série Antropologia, 64:1-9.

MARKOWITZ, Fran \& ASHKENAZI, Michael (eds.). 1999. Sex, sexuality, and the anthropologist. Urbana/ Chicago: University of Ilinois Press. 
. 1999. "Introduction: sexuality and prevarication in the praxis of anthropology". In: (eds.), Sex, sexuality, and the anthropologist. Urbana/ Chicago: University of Ilinois Press. pp. 1-22.

MELATTI, Júlio Cezar. 1985. "Curt Nimuendajú e os Jê". Série Antropologia, 49:25. Brasília: Fundação Universitária Brasília.

MENDONÇA, João Martinho de. 2000. Os movimentos da imagem da etnografia à reflexão antropológica: experimentos a partir do acevo fotográfico do professor Roberto Cardoso de Oliveira. Dissertação de Mestrado, Instituto de Artes da UNICAMP. 228 pgs.

MOREIRA NETO \& EMMERICH. 1977. "Introdução. Os índios Tukuna". Relatório enviado ao SPI (10/12/29). Boletim do Museu do Índio, 7:01-69. NIMUENDAJÚ, Curt. 1952. The Tukuna. Berkeley/ Los Angeles: University of California Press. . 1977 [1929]. "Os índios Tukuna". Relatório enviado ao SPI (10/12/29). Boletim do Museu do Índio, 7:01-69. . 2000. Cartas do Sertão. Correspondência entre Curt Nimuendajú e Carlos Estevão. Lisboa: Museu de Etnologia. . 2013 [1930]. "Visita aos índios Ticuna". Boletim do Museu Paraense Emílio Goeldi, 8(2):461-470.

NUNES PEREIRA, Manuel. 1946a. "Nimuendajú: A selva o devorou...".
Folha do Norte, Belém do Pará, 16/07/1946.

. 1946b. Curt Nimuendajú: síntese de uma vida e de uma obra. Belém do Pará. Mimeo. . 1980 [1967]. Moronguetá - Um decameron indígena. 2 vols. Rio de Janeiro: Civilização Brasileira. . 1978. "Entrevista". Revista HOJE, pp. 4-15, ago. 1978.

PACHECO DE OLIVEIRA, João. 1986. "O nosso governo": os Ticuna e o Regime Tutelar. Tese de Doutorado em Antropologia Social, Programa de Pós Graduação em Antropologia Social/ Museu Nacional, Universidade Federal do Rio de Janeiro, Rio de Janeiro, RJ. . 2013. "Curt Nimuendajú e a história Ticuna: elementos para uma reflexão crítica sobre a etnografia e o estatuto da etnologia". Tellus, 13(24):227-259.

SCHROEDER, Peter. 2013. "Primeira viagem aos Ticuna: um artigo pouco conhecido de Curt Nimuendajú". Boletim do Museu Paraense Emílio Goeldi, 8(2):461-470.

WELPER, E.M. 2002. Curt Nimuendajú: Um capítulo alemão na tradição etnográfica brasileira. Dissertação de Mestrado, Programa de Pós Graduação em Antropologia Social/ Museu Nacional-Universidade Federal do Rio de Janeiro, Rio de Janeiro, RJ. . 2013. "A aventura etnográfica de Curt Nimeundajú". Tellus, 24:99120. 
DA VIDA HERÓICA AO DIÁRIO ERÓTICO: SOBRE AS M ORTES DE CURT NIMUENDAJÚ

\section{Resumo}

Este artigo recupera os eventos que envolvem a misteriosa morte de Curt Nimuendajú (1883-1945) e conduz a uma reflexão sobre as dimensões pessoais do fazer etnográfico e o tema da identidade e da subjetividade erótica no trabalho de campo antropológico.

Palavras-chave: Curt Nimuendajú, Etnografia, Trabalho de campo, Antropologia brasileira, Índios ticuna.

\section{DE LA VIDA HEROICA AL DIARIO ERÓTICO: SOBRE LAS MUERTES DE CURT NIMUENDAJÚ}

\section{Resumen}

Este artículo recupera los eventos que rodean la misteriosa muerte de Curt $\mathrm{Ni}$ - muendajú (1883-1945) y conduce a una reflexión sobre las dimensiones personales del hacer etnográfico y el tema de la identidad y la subjetividad erótica en el trabajo de campo antropológico.

Palabras-clave: Curt Nimuendajú, Etnografía, Trabajo de campo, Antropología brasileira, Indios ticuna.

FROM THE HEROIC LIFE TO THE EROTIC DIARY: ON THE DEATHS OF CURT NIMUENDAJÚ

\section{Abstract}

This article recovers the events that led to the mysterious death of Curt Nimuendajú (1883-1945), analysing them in light of the personal dimensions of ethnographic research and of erotic identity and subjectivity in anthropological field work.

Key words: Curt Nimuendajú; Ethnography; Fieldwork; Brazilian Anthropology; Ticuna Indians. 
